\title{
Literature as a Medium of Exposing Social Problem through Thomas Gray's “Elegy Written in A Country Churchyard"
}

\author{
M. Manugeren, Jumino Suhadi \& Pardi Pardi \\ manugeren@sastra.uisu.ac.id, jumino.suhadi@sastra.uisu.ac.id, pardi@sastra.uisu.ac.id \\ Department of English Literature, Universitas Islam Sumatera Utara, Meda, INDONESIA
}

\begin{abstract}
Apart from being an entertainment medium, literature has also an important role in exposing social problems, as basically literature is born and is intended for the community. Through the disclosure of social problems, the role of literature is increasingly developing, among others, as a medium of teaching, reference, reflection, character building and also criticism. Thus, it is clearly illustrated that literature has multifunctional roles. The message conveyed through literature can be effectively absorbed by the community owing to the entertainment factor. Through the poem "Elegy Written in a Country Churchyard", Thomas Gray tells the story of the lives of marginal people, always having to face problems. Through descriptive qualitative research method, referring to social phenomena, supported by sociology of literature approach, the results of the study show that there are three social problems that always arise in the community, especially in the lower class one: poverty, right to get proper education and equality to obtain opportunities in the line of life. These three social problems are closely interrelated so that they become a unification undermining the lives of marginalized people.
\end{abstract}

Keywords: poverty, education, opportunity

\section{Introduction}

"Elegy Written in a Country Churchyard", a worldwide elegiac poem written by Thomas Gray (1716 - 1771) has earned him a respected and well-deserved spot in literary history (Shrestha, 2014). The thing that triggers this poem to become famous and enduring is the description of social problems commonly faced by poor people. In general, social problems are complex covering all elements of society. Thus, the social problem has always been the concern of all groups and subsequently, due to the popularity of this elegy, the word elegy is always coined with the name of Thomas Gray (1716 - 1771).
Elegy is generally considered to be a form of poetry that lends itself to contemplation or reflection. Its subject can be various but it must be treated not for itself but always in relation to the poet. The emphasis is on an absence, either a regret for something or someone lost in the past or a desire for an as yet unfulfilled future. Elegy presents things as lost and past, or absent and future (Jack, 2015). Elegy refers to poem or song containing lamentations and expressions of sorrow, especially in the event of death; not only death, the use of the word "elegy" in poetry or song lyrics can also be intended to describe the feeling of loss. The object described in an elegy is usually in the form of bitter experiences or of remorse or something is done in the past. Then elegy can also be used to express empathy for the misfortune experienced by others. 
As a literary work, elegy, which is also a poem, is a part of human life because basically, literature contains stories about humans, everything related to humans and their environment. Poetry, a genre in literature, cannot be separated from human life; this is in line with the literary concept stating that literature transcends national boundaries, time constraints, gender differences, and even historical basis. Literature is not tied to tempora spatio, being limited by space and time. (Manugeren and Hidayati in Hidayati, et.al, 2018).

From the perspective of the sociology of literature, literature and all the genres in it, are closely related to social problems, problems that are always faced by humans as a person or group. Literature expresses various problems in life. Literary work is a forum for expressing ideas, ideas, and thoughts with a picture of the experience. Literature presents the inner experience of the author to the reader or the public. Literature not only functions as a social reflection but also represents a picture or portrait of the world of social reality that transcends its time, with the understanding that literary works cannot be limited by time and space. Literature contributes to society in the form of contemplation to be further manifested in actions, both constructive or destructive in nature; all depends on perception in interpretation. The relationship between literature and society cannot be separated, because literature presents a picture of life over social reality.

That literature is a reflection of the society is a fact that has been widely acknowledged. Literature indeed reflects the society, its good values, and its ills. In its corrective function, literature mirrors the ills of the society with a view to making the society realize its mistakes and make amends. It also projects the virtues or good values in society for people to emulate. Literature, as an imitation of human action, often presents a picture of what people think, say and do in the society (Duhan, 2015). This is in line with Dubey (2013) stating that literature mirrors society. What happens in a society is reflected in literary works in one form or another.
Literature also acts as social control or social criticism. By this literature acts as a communication medium within the community that aims or functions as control over the course of a social system or social process. If literary works are used as a medium to convey criticism of social realities that are not in favor of the interests of society, then literary works actually have a social function. The social function of literary works is realized by responding to power functions carried out by leaders. The response given by literary works in the form of social criticism is directed to government or leaders having no concern in the interests of the people. The messages conveyed through literary works give warnings to those who have abused power. The social function of this literary work is expected to provide awareness to people to take action benefitting the interests of the public.

"Elegy Written in a Country Churchyard" is a communication medium for social criticism. Through this poem Gray (1716 1771 reveals the social problems faced by the community, especially those categorized as lower-class people or often termed marginal communities. Poverty is a real picture of this marginal society and poverty also triggers other social problems. Poverty is a problem marked by various things including the low quality of life of the people, the limited adequacy and quality of food, the limited and low quality of health, child nutrition, and the low quality of education.

Social problems focus on the breakdown of basic social institutions that must take care of individuals and assure the survival of the society and its social institutions (Mill in Kerbo and James, 2006). Social problems can also be interpreted as all forms of individual or group behavior that violate customs in people's lives. Social problems can disrupt a community's condition and are certainly undesirable, dangerous, and also detrimental to many people, disrupting the running social structure.

This research is related to the function of literature as a medium to express social problems through "Elegy Written in a Country Churchyard" by Thomas Gray (1716 - 1771 
with three points of discussion: poverty, right to get proper education and equality to obtain opportunities by means of the sociology of literature approach.

The approach to literary works by looking at values and functions in society is called the sociology of literature. This sociological approach includes various approaches using certain theories and attitudes. All of these approaches show one characteristic in common: to have a concern to literary works as a social correlation created by authors as members of society. The interrelationship between the author, the text and society is an integral part of the sociology of literature, which includes the social context of the author, the social function of literature and literature as a mirror of society.

The sociology of literature is a specialized area of study which focuses its attention upon the relationship between a literary work and the social structure in which it is created. It reveals that the existence of literary creation has determined social situations (Arisky, 2019)

In connection with the target analysis of "Elegy Written in a Country Churchyard" based on literary sociology, it is illustrated that Gray (1916-1771) in this funeral elegy, shows a keen interest in the life of humble people and village craftsmen. These poor, and insignificant people who lie in the churchyard, have in death, become equal to the most famous and prosperous men of all times: death comes to all men. He is able to express how all must die, and it does not matter if one is rich or poor, a noble or a commoner, or a poet or a politician. He is also able to elevate the common man with the elegy as a tool and his own freedom in the use of word power and poetic style, (Shrestha, 2014) and this is a picture of the author's social context in studying literature. Although literature is synonymous with beauty, the world of literature does not only talk about beauty, but also the meaning of life, love, and affection. Literary work contains critical ideas aimed at the government and social realities that are deemed incompatible with the hopes and interests of the community.
The initial draft of the poem was written in 1746 , and at that time Gray (1916 -1771) lived in a quiet village, Stoke Poges in England. Community life around him was very close to nature because the villagers were farmers; but behind all the calmness and peace of life, Gray observed that their lives were still far from the standard of worthiness and they were always not seen by the people of the city whose lives were more advanced. Gray provides a universal picture of the picture of poor people. Through this poem, the reader can see, feel and realize that economic stability determines one's social status.

The dominant social problems revealed in this poem are poverty, right to get proper education and equality to obtain opportunity in the line of life; said to be social problems because these three points can interfere with the stability of other social institutions. Poverty can trigger crime, and crime can disrupt the comfort and security of many people even to the problem of violence in the household. Educational institutions can also be disrupted by the development of poverty and all this is also due to the lack of equity in social and cultural issues, where only a group of people have the opportunity to improve their standard of living.

Social problems are conditions considered to be undesirable by many people. (Manis, 2014) and this is in line with Laue (2016) stating that social problems are said to exist when people define conditions as problematic. From these two concepts, it is illustrated that the points of discussion in this poem have fulfilled the criteria of social problems because they can cause social structure instability.

\section{Methodology}

This study was conducted by means of descriptive qualitative method (Miles, Hubeman and Saldana, 2014), as the points of discussion are related to social phenomena in which the focus goes to the members of society. The data were collected by using document studies, questionnaires, and interviews to support the analysis. The data obtained in the field were processed by using a qualitative frequency count. The data from 
questionnaires and interviews were used to find out that poverty, right to get proper education and equality to obtain opportunities in the line of life were parts of problematic issues in society and these points were oriented to the poor. The data trustworthiness is triangulation.

\section{Findings and Discussion}

Elegy Written in a Country Churchyard is published in four-line stanzas, or quatrains, where the first line is rhythmic with the third, the second with the fourth. This abab pattern, which is currently associated with Elegiac poem, provides the elegance for the poem. The last three stanzas are printed in italics and titled "The Epitaph."

Thomas Gray's Elegy Written in a Country Courtyard is one of the best known and most famous poems in English literature. Gray paints a calm scene of a poet walking through a cemetery behind a church. Listening to the cowbells ringing as the cattle return home and the church bells mark the end of the day, the speaker begins to ponder a simple graveyard and the people who lie buried beneath it: imagining their rural life and reflecting on how their daily tasks and worries do not give any effect in death, meaning that death does not distinguish between the rich and the poor. The speaker's mind moves forward into the future, imagining how others will see the speaker's own grave and read his writings there, the final melancholic approach to the inevitable death. All that beauty, all that wealth, all the power will sooner or later come to nothing.

The poem gives a vivid picture of the life of the villagers blended with an impressive narration of the beauty of nature; however the villagers, lacking of knowledge and wealth, keep on expressing gratitude upon all the blessings they have got.

This poem begins with a beautiful and fitting description of nature at dusk. The words' toll ', parting day' and 'darkness' remind the reader that life is only temporary, no one can escape the reality of the lifeline; everyone will die, and death does not distinguish between the rich and the poor - 'all await the inevitable hour'. Therefore bragging of power, wealth or beauty is a useless thing because, by the passing of time everyone, everything will fade away and disappear.

Images of happiness of villagers or financially disadvantaged people are beautifully presented in this poem; a wife busy preparing dinner for her husband and children, and there is also a picture of children welcoming their father's arrival with joy and sincerity. This is a portrait of the life of a village life full of peace and happiness. They live in harmony not only with fellow family members but also with the environment and nature. All this may not be found in the lives of city people who are always busy with world affairs neglecting in managing domestic life and as a result people in the city, though not all, are more often dissolved in inner chaos and mind.

Then, the poet gives a picture of the village cemetery s only decorated with very simple signs because basically, they are not able to make the luxurious graves commonly found in the city. Actually, all the expensive and luxurious ornamentation placed in the grave is actually meaningless; just a matter of pride. No matter how great the decoration given at the grave, a person who has died will never return.

There is a very sad thing in this poem. Poor people are always treated unfairly. They do not get the chance to improve their lives; even though many of them have extraordinary talent and intelligence; but all the greatness they have, vanished in time-consuming because they can never come to the surface level.

\section{Poverty}

Poverty is a condition where a person is unable to fulfill his basic needs such as food, clothing, shelter, education, and proper health. Quantitatively, poverty is a condition where the standard of living of people is completely lacking or does not have assets; while qualitatively, the notion of poverty is an unfit state of human life. Poverty is a human condition characterized by sustained or chronic deprivation of the resources, capabilities, choices, security, and power necessary for the enjoyment of an adequate 
standard of living and other civil, cultural, economic, political and social rights. (Shillington, 2009)

Poverty as a complex social problem is illustrated through these lines:

\section{Let not Ambition mock their useful toil, Their homely joys, and destiny obscure; Nor Grandeur hear with a disdainful smile The short and simple annals of the poor. (Gray, 2015, p. 8)}

Here it is exposed that the poor are always underestimated, will not be heard and even always ignored. They are always considered non-existent. The word 'Ambition' with the initial capital in stanza 8 is a personification of people of the upper class. The word 'Ambition' refers to people who are ambitious in life and those people with high ambition are always racing against highly coveted goals. Such people always legalize all means to achieve their goals. In this case, the rich people or people who are in the upper class always harass the work of villagers who are generally farmers. Basically, becoming a farmer is a noble job, and simply owing to the insufficient, consequently, they fall into the category of poor people. Then it is also expressed here in a contemptuous tone that the fate of the poor is uncertain and the entertainment they have is also very limited because they cannot afford to go on holiday abroad or to other luxurious resorts. The story of the poor is also very simple; or nothing can be related to the lives of the poor, everything is monotonous.

Through this stanza, as a medium of social problem disclosure, the poet conveys a message to everyone not to put down the lives of the poor at all because poverty is not a life choice. Poverty is a complex social problem related to various factors; therefore the government must pay attention to the fate of the poor and at the same time find solutions to overcome poverty. Poverty will certainly trigger other social problems. below.

Another illustration of poverty is shown

Nor you, ye proud, impute to these the fault, If Mem'ry o'er their tomb no trophies raise,
Where thro' the long-drawn aisle and fretted vault

The pealing anthem swells the note of praise. (Gray, 2015, p.10)

Through this stanza, the poet gives a message, especially to the upper-class people, and people who always underestimate the poor that no one wants to be a poor person having to live the life of difficulty. Being poor is not a choice, but a line of life. The graves of the poor are not provided with fancy decorations or memorials and this is not their fault; they are indeed unable to complete their graveyards with luxurious goods. For them to be able to fulfill their basic needs, namely food, is already more than enough. They live from hand to mouth, or else they have to maintain life from day to day. Lacking is a feature of the lives of the poor. Then there is no reason for anyone to underestimate their lives; instead, the rich or people who have power must find solutions to improve their lives as this is a problem of humanity.

Then, the poet also gives a picture of the injustice always experienced by the poor. The poor die and very few people come to the funerals or graves; but when a rich person dies, lots of mourners come. All forms of praises in the form of words, speeches or songs are echoed to honor and entertain the families of the rich who are left behind. This phenomenon is not only found in England of the poet's, but is universal, meaning that the same thing can be found in today's society. Poor people are always marginalized.

\section{Right to Get Proper Education}

The discussion refers to the right of individuals to obtain a proper education. The claim that a right to education is a human right is an important claim. It is an important claim because there is a responsibility to enable children to develop an acquired set of capabilities to lead their own lives in a meaningful and fulfilling way (Lee, 2013)

Every individual has the rights and obligations, including the right to obtain a proper education. Education does not look at race, class or religion. Whatever the background of an individual, he is entitled to 
obtain a proper education. But in reality, not everyone can get a proper education, especially those who live below the line of the worthiness of life. Poor people find it difficult to obtain the education, especially in this day as education has become an industry, so the costs are adjusted to the condition of a developing economy,

\section{But Knowledge to their eyes her ample page \\ Rich with the spoils of time did ne'er unroll; Chill Penury repress'd their noble rage, \\ And froze the genial current of the soul. (Gray, 2015, p. 13)}

The results obtained from the activities of reading, observing, learning, and understanding the conditions existing around the environment is a manifestation of the learning process which is certainly related to knowledge. By knowledge, life becomes easy because knowledge is also a tool for living life. From a scientific point of view, knowledge is not just information obtained from various sources, but a set of information supported by an agreed theory and systematically tested by agreed methods, thus knowledge is an integral part of human life and at the same time make it easy for humans to carry out their duties and functions.

Theoretically, knowledge is open to anyone, but reality speaks differently. In this poem it is illustrated that the poor do not have the opportunity to obtain proper education, of course the education referred to here is formal education. The word 'did ne'er unroll' describes that knowledge is not open to all people, and in this case, those who are less fortunate to get into education are poor people.

Their name, their years, spelt by th' unletter'd muse,

The place of fame and elegy supply:

And many a holy text around she strews,

That teach the rustic moralist to die.

(Gray, 2015, p. 21)

This stanza gives a picture of the simple graveyard of the poor. Nothing extraordinary is found here; there is only a simple sign of the existence of a person buried. The poor with no proper education are unable to write the names of the deceased on the tombstone well; they write names with letters that are difficult to read because they are not able to write and read well because they do not get a formal education.

But behind all this, there is something to be proud of from their graveyards. They never forget to be grateful for what they have obtained from God, the Almighty even though they live in difficulty. This can be seen from the sentences, phrases or words they write on their tombstones which they quote from the holy scriptures. They do not get proper education, formal education, but they still get moral education that keeps them focused on running their lives. It is this morality that makes them good people, people who are always happy and calm because they know that God must have other better plans for them. They may be poor in this life but rich in the next life. This is what is termed a firm faith.

\section{Equality to Obtain Opportunity in the Line of Life}

The notion that individuals ought to have equal opportunities in life is popular among politicians, the general public, and philosophers alike (Mahler, and Xavier, 2017. For this reason, the philosophers who advocate for equality of opportunity do not advocate for equality of opportunity for income acquisition, but rather something broader than income such as welfare or advantage (Anerson and Cohen in Mahler, and Xavier, 2017)

In this case what is meant by equal rights to get opportunities is not related to income problems because one's income is determined by various factors, such as educational, social, cultural and also talent backgrounds; but everyone must be given the opportunity to obtain something without any reason. This is conveyed by Gray (2015) where he sees that poor people in no way are given the opportunity to organize a better life.

Perhaps in this neglected spot is laid Some heart once pregnant with celestial fire; 
Hands, that the rod of empire might have sway'd,

Or wak'd to ecstasy the living lyre.

(Gray, 2015, p. 12)

Success in life is not only determined by intelligence, or morality. The opportunity factor also plays an important role. No matter how smart or good a person is, he will not succeed if he does not get a chance. In reality, not all people get opportunities, especially in improving their welfare. Poor people always get discrimination in the matter of opportunity. Through this stanza, the poet gives a message or a description that the person buried in the village cemetery can be great leaders, musicians or a scientist; but because they do not get the opportunity in all lines of social life, they can only live and die without being recognized.

\section{Full many a gem of purest ray serene,} The dark unfathom'd caves of ocean bear: Full many a flow'r is born to blush unseen, And waste its sweetness on the desert air. (Gray, 2015, p. 14)

Opportunities to improve the welfare of life are minimally given to the poor, even almost none, as a result, no matter how big the potential of the poor is, it is not visible. This description is conveyed by the poet in this stanza by giving an analogy; just like the gemstones on the seabed, however beautiful they are, they are of low value because they are invisible and difficult to reach. Likewise, a variety of beautiful flowers growing in the desert is also not seen. These flowers grow and wither away, without anyone being able to enjoy their beauty. Poor people are also like that, born, live and die without coloring life. This is a very sad phenomenon. In short, the poor only live to die.

The data listed above give input to everyone that life is regulated or structured as it is; some are rich, some are poor, some have positions, some live like ordinary people. Being rich, poor, or powerful can be interpreted from two points of view. First, the success of a person depends on the effort done to achieve the goal. The first perspective shows that someone could determine his own destiny, or often referred to as character is destiny. In the second perspective, a person's destiny is inseparable from the direction of life, which means that life is not a choice. But whatever perspective is held, to put others down is not a good policy.

The rich or those in power are often careless in interpreting life and assume that they are the most righteous and respected and must be heard. They forget that life on earth is temporary, everything is mortal because in due course everything will disappear. There is no single condition that can survive, no wealth can survive, as well as all forms of ownership; all are sure to be lost in the passing of time. What is left and counted from a person is his faith, charity, and worship. People are valued not because of their ownership, but good morality they have. Immoral people who are not valued are not poor. The immoral are not respected, not the poor. There is nothing wrong to live in poverty, from a moral viewpoint.

Poverty is experienced by various countries, especially third countries where the population lives below the poverty line; they are only able to meet their food needs, even for the food they sometimes face difficulties. Instinctively, no one wants to live in poor and difficult conditions. Everyone must expect a steady and fulfilling life. Actually being rich or poor is a trial for those whose faith has not been shaken by circumstances.

\section{Conclusion}

There are three distinctive points of discussion in this poem: poverty, right to get proper education and equality to obtain opportunities in the line of life; all three are interrelated social issues. Through this poem, the poet conveys a message that social problems must be a concern for all.

This poem as a literary work is a medium to express social problems. A literary work is a form of cultural creativity and representation of ideological superstructures. Social criticism in a literary work is a form of communication in a society aiming to control the course of a social system or social process. Literature is considered the most powerful in carrying out 
social criticism towards the existing power deviating from the norm.

Literary works are inseparable from social and cultural problems and people's lives. Literary works are written by writers, not for their own circles, but to be delivered to the wider community. Through the results of writings, a writer submits ideas, suggestions, and criticisms to be followed upon.

Literature is perfected by social phenomena. Literature is not born without intellectual thought; literature is born from the mirror of human life. A literary work, in general, is not only capable of presenting a series of words and aesthetic and fresh language but also contains profound meanings, both implied or intentionally confirmed by the author. Besides, literary work also provides a new inner experience, awakening the reader to the essential values of life. Literature is not merely an entertainment of the poet's loneliness, but a reflection of social life that can enlighten the community.

\section{Acknowledgments}

Expressions of gratitude are conveyed to the Faculty of Literature, Universitas Islam Sumatera Utara, Medan dan Lembaga Penelitian UISU (UISU Research Unit) for the facilities provided for this study.

\section{References}

Arisky, Huzain. (2019). The Sociology of Literature: Theoretical Premises. Academia. Retrieved from https:// www.academia. edu/30119257/

Dubey, Arjun. (2013). Literature and Society. IOSR Journal of Humanities and Social Science. 9(6). Retrieved from http: //iosrjournals.org/iosr-jhss/papers /Vol9-issue6/00968485. pdf?id=6191

Duhan, Roshni. (2015). The Relationship between Literature and Society. Language in India. 15(4). Retrieved from http://www.languageinindia.com/ april2015/roshiniliteraturesociety1.pdf

Gray, Thomas. (2015). Elegy Written in a Country Churchyard. Bartleby. Com. Retrieved from https://www.bartleby. com/101/453.html

Hidayati, et.al. (2018). The Poor in Thomas Gray's Elegy Written in a Country Churchyard: Critical Discourse Analysis Approach. Language Literacy: Journal of Linguistics, Literature and Language Teaching, 2(2). https://doi.org/10.30743 /ll.v2i2.717

Jack, Belinda. (2015). Poetry and Remembrance: Thomas Gray's Elegy Written in a Country Churchyard. Gresham College. Retrieved from https://pdfs.semanticscholar.org/254e/2 cdc1b08b4ad271fe79148248b9f0b0f441 a.pdf

Kerbo, H. R., \& Coldeman, J. W. (2006). Social Problems. California: Pearson Education. Retrieved from https://www. researchgate.net/publication/46572319_ Social_Problems

Lauer, Robert H. (2016). Defining Social Problems: Public and Professional Perspective. Social Problems, Volume 24, Issue 1, 1 October 1976, Pages 122-130, https://doi.org/10.2307/800329

Lee, S. E. (2013). Education as a Human Right in the 21st Century. Democracy and Education, 21 (1), Article 1. Retrieved from https://democracyeducationjournal .org/home/vol21/iss1/1

Mahler, D. G. \& Ramos, X. (2017). Equality of Opportunity for Well-Being. Bellaterra: Universitat Autonoma de Barcelona. Retrieved from http://ftp.iza.org/ dp10940.pdf

Manis, Jerome G. (2014). The Concept of Social Problems: Vox Populi and Sociological Analysis. Social Problems, 21(3), 305-315. https://doi.org/10.2307/799900 
Miles, M. B., Huberman, A. M., \& Saldana, J. (2014). Qualitative data analysis: A methods sourcebook. 3rd Ed. Thousand Oaks, CA: Sage.

Shillington, Richard, et.al. (2009). The Meaning of Poverty. Informetrica Limited. Canada: Informetica Limited. Retrieved from https://metcalffoundation.com/wpcontent/uploads/2011/05/fog-workingpaper-01.pdf.

Shrestha, Muna. (2014). An Elegy Written in a Country Churchyard, Gray Expreses the Sympathy for the Common Man. Language in India. 14(10). Retrieved from http://www.languageinindia.com /oct2014/munagrayelegyfinal.pdf 